\title{
1. The proliferation of EU enforcement authorities: a new development in law enforcement in the EU
}

\author{
Miroslava Scholten, Michiel Luchtman and \\ Elmar Schmidt
}

\section{INTRODUCTION}

Recently, the powers of the European Union (EU) have evolved from being mainly regulatory to include also direct enforcement competences. Rather than monitoring the enforcement efforts of national authorities (indirect enforcement), direct enforcement by the EU implies that EU enforcement authorities (EEAs) have the power to monitor adherence to legal rules by private actors, as well as to investigate and sanction alleged violations of EU law by those actors. The shift of power from the national to the EU level, especially in such an area as law enforcement, raises concerns about how to ensure democratic control and the rule of law. These concerns are not without valid reasons. ${ }^{1}$ In the light of such concerns, the aim of this edited collection is to analyse whether and how the shift of direct enforcement power to the EU level has been accompanied by establishing relevant accountability systems. What challenges in terms of democratic control and the rule of law does this development bring about and how could or should those challenges be addressed?

Since 1999, the number of EEAs has grown from one to eight: the Commission (Directorate-General for Competition, 'Directorate-F' (on food law) and the Anti-Fraud Office/OLAF); European Medicines

1 The European Court of Auditors (ECA) has recently concluded that the efforts of the European Central Bank to ensure transparency and accountability before the European Parliament are weakened by the lack of a proper accountability mechanism (ECA's Special Report No 29/2016, Single Supervisory Mechanism - Good start but further improvements needed, p. 10). 
Agency (EMA); European Aviation Safety Agency (EASA); European Fisheries Control Agency (EFCA); European Securities and Markets Authority (ESMA); and the European Central Bank (ECB). The list is exhaustive (see Annex below). In addition, since 2013, legislative negotiations have been ongoing on the design and powers of a European Public Prosecutor's Office (EPPO) envisaged by the Treaty of Lisbon (Article 86 Treaty on the Functioning of the European Union (TFEU)). What can EEAs do? Depending on the statutory remit, they can monitor behaviour of private parties, such as airline companies and banks. If a violation of relevant EU law by the private party is suspected, the EEAs can investigate the alleged violation, including conducting an on-site inspection at the business premises of the private party. If the violation has been proved to occur, they can punish via imposing fines and/or supervisory measures, like public notices and revocation of a permit.

The proliferation of EEAs can be explained by the desire to promote the at-times problematic implementation of EU policies and the (uniform) compliance with EU law, as well as to fight the limits of the "traditional tool' of indirect enforcement via the Commission. ${ }^{2}$ It is likely to take place in those policy areas where implementation by national authorities has been or could have been problematic. ${ }^{3}$ Assigning EU authorities tasks in the area of law enforcement can resolve problems of transnational enforcement, because expertise and capacity are thus combined with the advantages of what is called 'European territoriality'. ${ }^{4}$ Whereas national borders bind the enforcement jurisdiction of national authorities, the territorial competences of EU authorities include the joint territories of all the participating Member States (MS). Depending on their specific institutional designs, these advantages gain even greater weight when time-consuming schemes for mutual legal (administrative or criminal law) assistance are removed from their legal design. In this case, EU authorities can have the legal power to gather information anywhere in the EU.

2 A de Moor-van Vugt and R Widdershoven, 'Administrative Enforcement' in J Jans, S Prechal and R Widdershoven (eds), Europeanisation of Public Law (Europa Law Publishing 2015); M Scholten, 'Mind the Trend! The Enforcement of EU Law is Moving to "Brussels" (2017) 24 Journal of European Public Policy 9, 1348.

3 M Scholten and D Scholten, 'From Regulation to Enforcement in the EU Policy Cycle: A New Type of Functional Spillover?' (2017) 55 Journal of Common Market Studies 4, 925.

4 C Ryngaert and J Vervaele, 'Core Values Beyond Territories and Borders The Internal and External Dimension of EU Regulation and Enforcement' in T van den Brink, M Luchtman and M Scholten (eds), Sovereignty in the Shared Legal Order of the EU-Core Values of Regulation and Enforcement (Intersentia 2015). 
Whatever legislative and institutional design is chosen, it is important to stress that none of the EEAs entirely replaces their national counterparts, i.e. the competent national enforcement authorities (NEAs). This is why we speak of enforcement in a shared legal order. By that, we mean that in the enforcement of EU policy areas both the EEAs and their national partners have their own tasks in enforcement, which are inter-dependent. For the EU policies to be implemented and enforced effectively, both the EU and national authorities need to discharge their respective tasks. The precise content of the tasks and the division of labour between the national and EU level differ, depending on the specific policy area. ${ }^{5}$ In some cases, for instance, EEAs have taken charge of the enforcement policy and process, while in other cases they support NEAs in performing one or other of the enforcement tasks.

On a similar note, we see that the legislative framework, in which the tasks and powers of the authorities are defined (together with the relevant safeguards and remedies), are not defined only by EU law. Rather, these frameworks are often decentralized and integrated into the legal regimes of the MS. This means not only that the EU authorities sometimes have to apply national law, like the ECB or the EPPO, but also that there is no (or only a rather limited) level playing field of substantive norms, tasks, investigative powers, et cetera.

The shift of power from the national to the EU levels, together with the sharing of enforcement tasks in a vertical setting (state - EU) as well as a horizontal setting (state - state), has triggered concerns that these developments are not matched with appropriate levels of political control and accountability and that they can also put the protection of fundamental rights at risk. ${ }^{6}$ Political and judicial control and accountability are deemed essential to enable a democratic forum to monitor the use of public power

5 cf the definition of Committee of Independent Experts, Second Report on Reform of the Commission, Analysis of Current Practice and Proposals for Tackling Mismanagement, Irregularities and Fraud (10 September 1999), Vol. I, para 3.2.2, 78; E Schmidt-A $\beta$ mann, 'Introduction: European Composite Administration and the role of European administrative law' in O Jansen and B Schöndorf-Haubold (eds), The European Composite Administration (Intersentia 2011); Jans, Prechal and Widdershoven (n 2) 7-9.

6 M Bovens, D Curtin and P 't Hart, 'The EU's Accountability Deficit: Reality or Myth?' in M Bovens, D Curtin and $\mathrm{P}$ 't Hart (eds), The Real World of EU Accountability: What Deficit? (OUP 2010) 5; K Ligeti and A Marletta, 'EU Criminal Justice Actors: Accountability and Judicial Review vis-à-vis the EU Citizen' (2016) 7 New Journal of European Criminal Law 175; M Luchtman and J Vervaele, 'European Agencies for Criminal Justice and Shared Enforcement (Eurojust and the European Public Prosecutor's Office)' (2014) 10 Utrecht Law 
by the executive branch; to prevent or punish abuses of power; to ensure the rule of law; and to learn from the mistakes made. ${ }^{7}$ Furthermore, accountability is instrumental to promoting legitimacy, which has been contested in the EU context.

The aim of this edited collection is to analyse whether and how the shift of direct enforcement powers to the EU level has been accompanied by an accountability system suited to address the needs of a shared EU legal order. We have - based on a common analytical framework (see section 4 below) - analysed all existing eight EEAs and the currently non-existent EPPO and their relationships with the national partners in various EU policy areas. In addition, we have drawn up a series of conclusions from the comparisons between these areas in horizontal studies. More specifically, this book's focus is on the challenges for EU law enforcement in terms of political and judicial accountability and on how these challenges are addressed in the various policy areas, with a view to identifying common problems, as well as the emergence of best practice.

\section{KEY CONCEPTS}

\subsection{What is Enforcement?}

Enforcement is an essential task for government in any legal system. ${ }^{8}$ It is a public action 'with the objective of preventing or responding to the violation of a norm' . 'Such prevention or response consists of three elements, as identified by Vervaele:

Enforcement of Community law deals with the enforcement of regulatory programmes, which is part of the implementation of EC policy. Enforcement is always linked to the substantive rules to be enforced (the policy-area) and is highly dependent on the implementation of rules. In that sense there is a strong link between norm-setting, implementation and enforcement. Hence, law

Review 132; H Hofmann, G Rowe and A Türk, Administrative Law and Policy of the European Union (OUP 2011).

7 M Bovens, 'Analysing and Assessing Accountability: A Conceptual Framework' (2007) 13 European Law Journal 447.

8 W Duk, Recht en Slecht: Beginselen van een Algemene Rechtsleer (Ars Aequi Libri 1999).

9 V Röben, 'The Enforcement Authority of International Institutions' in R Wolfrum, A von Bogdandy, M Goldmann and P Dann (eds), The Exercise of Public Authority by International Institutions: Advancing International Institutional Law (Springer 2009) 821. 
enforcement comprises monitoring, investigating and sanctioning violations of substantive norms. ${ }^{10}$

The term includes 'all types of controls conducted by regulatory agencies and all of their potential follow-up measures (sanctions, prosecutions etc.), as well as activities of law-enforcement bodies that are not primarily "business regulators" (e.g. the police, prosecutors etc.).".

The foregoing implies that we take a broad definition of enforcement, or law enforcement. We do not limit ourselves to the narrow definition of law enforcement as the activities by the police (or specialized counterparts) in the area of criminal law. Our approach is broader. More specifically, 'monitoring' is defined in this project as the process of ongoing supervision of a certain policy area, e.g. banking supervision. It can target a specific group, e.g. those who have received a permit to offer banking services, but it may also involve general market oversight. The stage of monitoring usually involves the use of powers without there being a need for a certain degree of suspicion. That would run counter to the general purpose of monitoring, which is to check whether individuals and economic operators adhere to the law. 'Investigations' refer to inquiries by the authorities on the basis of some degree of suspicion that there has been an infringement of the law. The goal is to gather information with a view to collecting evidence to establish such violation and to decide on the course of further action on the basis of that. Investigations may take place on the basis of administrative or criminal law. Finally, 'sanctioning' is defined as the formal reaction to a violation of the law by the authorities. Sanctions may have a restorative character, but they can also be of a punitive nature. ${ }^{12}$

\subsection{Direct and Indirect Enforcement of EU Law}

Public administration requires two areas of activity: the internal supervision of the institutions and officials that form part of the public administration on all levels, and 'the external enforcement of the law vis-à-vis

10 J Vervaele, 'Shared Governance and Enforcement of European Law: From Comitology to a Multi-level Agency Structure?' in C Joerges and E Vos (eds), EU Committees: Social Regulation, Law and Politics (Hart Publishing 1999) 131.

11 F Blanc, Inspection Reforms: Why, How, and With What Results (OECD Publication 2012) 5.

12 cf ECtHR 21 February 1984, Öztürk v Germany, appl. no. 8544/79; see also ECJ 5 June 2012, Case C-489/10, Eukasz Marcin Bonda, discussed by A de Moorvan Vugt, 'Administrative Sanctions in EU Law', (2012) 5 Review of European Administrative Law 5. 
those who are subject to it' ${ }^{13}$ From this distinction follows an identification of the two accompanying types of control used to achieve the desired control: direct control and control over implementation, i.e. a function of the tasks carried out. In this context, direct control is enforcement action taken by EU or MS authorities and aimed directly at EU citizens and economic actors. This type of control is also known as first-line control, ${ }^{14}$ and will be referred to as direct enforcement below. Control over implementation, or second-line control, 'involves the supervision of the application of the law by public authorities - and foremost of the Member States - but not directly over whether citizens as such obey it'. ${ }^{15}$ In what follows, this type of enforcement will be referred to as indirect enforcement. It does not form part of this volume.

Direct enforcement, the focus of this project, implies a situation when EU actors such as the Commission or an EU agency are in charge of enforcement and use such powers directly against citizens and private companies. ${ }^{16}$ Initially, this existed only in the field of EU competition law. High-profile cases such as the Google ${ }^{17}$, Intel ${ }^{18}$ and Microsoft ${ }^{19}$ cases clearly display a very real direct power that the EU possesses when it comes to enforcement of its policies and enforcing these directly against citizens and companies. However, the 'rule' that enforcement of EU policies is generally indirect is losing ground. ${ }^{20}$ As was mentioned above, a clear trend has emerged where enforcement powers that were once in the hands of the MS have been transferred to the EU. This makes the issue of how these authorities account for the execution of their tasks a highly relevant one. Can we still rely on the existing regimes for account-

13 Hofmann, Rowe and Türk (n 6).

14 G Rowe, 'Administrative Supervision of Administrative Action in the European Union' in H Hofmann, G Rowe and A Türk (eds), Legal Challenges in EU Administrative Law: Towards an Integrated Administration (Edward Elgar Publishing 2009) 188-217.

15 Ibid.

16 Scholten (n 2).

17 European Commission, 'Antitrust: Commission sends Statement of Objections to Google on comparison shopping service; opens separate formal investigation on Android' (Press Release) IP/15/4780.

18 Intel (Case COMP/C-3/37.990) Commission Decision 227/07 [2009] OJ C 227/13.

19 European Commission, 'Antitrust: Commission accepts Microsoft commitments to give users browser choice' (Press Release) IP/09/1941.

20 H Hofmann and A Türk, 'The Development of Integrated Administration in the EU and its Consequences' (2007) 13 European Law Journal 253; H Hofmann and A Türk, Legal Challenges in EU Administrative Law: Towards an Integrated Administration (Edward Elgar Publishing 2006) 3. 
ability - mostly developed for regulatory tasks or for the implementation of EU policies - or do tasks in the sphere of law enforcement (monitoring, investigation, sanctioning) call for specific arrangements?

\subsection{What is Accountability?}

When it comes to defining accountability, there are a great many meanings. On the one hand, these definitions differ and are used at times interchangeably with such notions as responsibility, responsiveness and control, which can be misleading. On the other hand, a number of leading definitions actually overlap. According to the World Bank: 'accountability exists when there is a relationship where an individual or body, and the performance of tasks or functions by that individual or body, are subject to another's oversight, direction or request that they provide information or justification for their actions' ${ }^{21}$ One of the leading definitions in the accountability scholarship - that of Bovens - has the following elements: (1) there is a relationship between an actor and a forum (2) in which the actor is obliged (3) to explain and justify (4) his conduct (5) and the forum can pose questions, (6) pass judgment and (7) the actor may face consequences. ${ }^{22}$

The definitions are similar, but with some differences. Bovens included the possibility of asking questions, though that option can be said to be implicit in the World Bank's requirement of providing information. The three stages identified by all authors contain the three phases of providing information, discussing that information and, finally, rectification. All three stages are important as '[w]ithout information, discussion is futile; having information without a possibility of discussion can prevent the rectification of mistakes; accountability without sanctions is incomplete as the presence of a possibility to sanction makes the difference between noncommittal provision of information and being held to account'. ${ }^{23}$ In this book, we follow these three stages based on the definition provided by Bovens.

We must note that this narrow definition of accountability does not coincide with the wider concept of control, where accountability is only a part of ex ante, ongoing and ex post control (the last-named being

21 R Stapenhurst and M O'Brien, 'Accountability in Governance' (unpublished) World Bank Paper.

22 Bovens, Curtin and Hart (n 6).

23 M Scholten, "Independent, Hence Unaccountable'? - The Need for a Broader Debate on Accountability of the Executive' (2011) 4 Review of European Administrative Law 5. 
accountability). ${ }^{24}$ In relation to law enforcement, control also involves such issues as the ability of the law to vest the authorities at the EU and national levels with monitoring, investigative and sanctioning powers, while simultaneously limiting those authorities with its preconditions. It is therefore a wider concept than accountability, also including ex ante (legislative or other) steering and guidance. Brought back to its basics, legal doctrine in law enforcement has always held that a key function of the law is to keep executive (and judicial) discretion at bay. By defining the tasks and powers of the authorities, but also by organizing checks and balances - for instance through ex ante judicial control - the rule of law aims to prevent state power from being exercised in a random, arbitrary manner. Control is thus inextricably related to such concepts as democracy, separation of powers, fundamental rights and - in more general terms - the rule of law.

In the shared legal order of the EU, a comprehensive analysis of control would invoke many profoundly interesting questions pertaining to, inter alia, the determination of the applicable legal regime by EEAs and the ability of these authorities to evade legal (or other) restrictions of one legal order by moving investigations or prosecutions to another. Given the fact that these authorities can operate all over the EU, but do so in a decentralized setting of different national laws, these questions definitely need attention. They involve both the vertical relationship between the EU and the national legal orders, and also the horizontal relationships between the EU Member States. For instance, can the EU authorities, by locating their activity within one territory (instead of another), determine the applicable legal regime of all actors in the procedure (determining the powers, safeguards, remedies, etc.)? This would imply that cooperating (criminal law) authorities could, e.g. evade Polish procedural safeguards by performing an online computer search in, say, France and subsequently using the obtained information in Polish proceedings. Here, there is a risk of forum shopping or a race to the bottom. ${ }^{25}$

A full inclusion of these issues in the analytical framework in this volume would make this project impossible to manage. Nonetheless,

24 M Busuioc, 'Accountability, Control and Independence: The Case of European Agencies' (2009) 15 European Law Journal 599.

${ }_{25}$ K Ligeti and M Simonato, 'The European Public Prosecutor's Office: Towards a Truly European Prosecution Service?' (2013) 4 New Journal of European Criminal Law 7; M Luchtman and J Vervaele, 'Enforcing the Market Abuse Regime: Towards an Integrated Model of Criminal and Administrative Law Enforcement in the European Union?' (2014) 5 New Journal of European Criminal Law 192. 
issues related to forum shopping do come up on occasion, for instance in competition law where different policies of leniency have been said to induce forum shopping (by enterprises) and thus underlining the need for accountable case allocations. ${ }^{26}$ Similar concerns are currently on the agenda in the negotiations on the EPPO. The following two points are therefore included in this project, where relevant, for the case studies:

1. the issue of if and how forum choices are accounted for and before which forums (judicial/political); and

2. the issue of to what extent ex post accountability mechanisms can compensate for a decentralization of ex ante control (legislative steering and judicial control). This issue is almost inextricably linked to the workings of a shared legal order where centralized law enforcement and EU-wide, uniform rules of procedure face many other objections (sovereignty, subsidiarity, etc.).

\subsubsection{Political and judicial accountability}

A pertinent issue in academic scholarship is to what extent the many different forms of accountability (political, judicial, financial, administrative, etc.) cause unnecessary overlap in accountability relationships or help to close gaps and ensure a watertight system of accountability. In this book, we focus on two types of accountability, namely judicial and political accountability, as well as their mutual relationships. Judicial accountability, as defined in this book, pertains to the ex post accountability before a court or judge, whereas political accountability relates to the accountability by representative institutions. Our departure point is that enforcement, whether arranged at the EU or national level, or as a shared activity, not only pursues a general interest, but also involves deeply intrusive interferences with the rights and liberties of individuals. This calls for a balanced system of accountability, capable of keeping track of the general priorities by the bodies that represent the general interest, as well as of protecting the interests of individuals or companies (as defendants, victims, or in whatever other capacity) in specific cases.

The two types of accountability are certainly not interchangeable. Their

26 S Brammer, Co-operation Between National Competition Agencies in the Enforcement of EC Competition Law (Hart 2008); F Rizzuto, 'Parallel Competence and the Power of the EC Commission under Regulation 1/2003 According to the Court of First Instance', (2008) 29 ECLR 286; A Schwab and C Steinle, 'Pitfalls of the European Competition Network - Why Better Protection of Leniency Applicants and Legal Regulation of Case Allocation is Needed', (2008) 29 ECLR 523. 
distinction builds on a strong normative background. In relation to law enforcement, political accountability - even for independent agencies - is considered particularly important with respect to the development of the general investigative, prosecutorial and sanctioning policies (where relevant). ${ }^{27}$ If enforcement authorities have the power to formulate and execute enforcement policies in specific sectors of EU law, a democratic system of government requires accountability for the policy choices before the people. In a representative democratic system, like the EU (Article 10 of the Treaty on European Union (TEU), the mechanism of political accountability (an executive body - representative body) is the means to promote democratic accountability of the government.

In line with this, Recommendation Rec(2000)19 of the Committee of Ministers of the Council of Europe on the 'Role of Public Prosecution in the criminal justice system' for instance holds that:

States should take appropriate measures to ensure that public prosecutors are able to perform their professional duties and responsibilities without unjustified interference or unjustified exposure to civil, penal or other liability. However, the public prosecution should account periodically and publicly for its activities as a whole and, in particular, the way in which its priorities were carried out.

To enhance the effectiveness of enforcement, public supervisors normally enjoy independence from political influence and from the relevant sector's influences. ${ }^{28}$

It appears to be a common characteristic of all Western legal orders that political interference with individual cases is an absolute 'no-go area'. The Venice Commission has, for instance, said that with respect to prosecutorial accountability, there is a need to differentiate between democratic/ political control over the general policies and the respect for prosecutorial independence in a specific case. For investigatory activities, the need to protect ongoing investigations may be another reason for non-interference by political actors. ${ }^{29}$

27 See for instance the many recommendations on this by such authoritative forums as the Venice Commission or the Council of Europe; cf the European Commission for democracy through law (Venice Commission), Strasbourg, 30 June 2015, CDL-PI(2015)009, Compilation of Venice Commission opinions and reports concerning prosecutors.

28 A Ottow, Market and Competition Authorities: Good Agency Principles (OUP 2015).

29 Venice Commission (n 26). See also Gerard Conway 'Holding to Account a Possible European Public Prosecutor-Supranational Goverance and Accountability across Diverse Legal Traditions', (2013) 24 Criminal Law Forum 371; P Tak (ed.), 
The (constitutional) imperative for political actors to refrain from interference with specific cases is supplemented by forms of judicial control and judicial accountability. This applies particularly where fundamental rights are at stake, as is often the case in law enforcement. In those instances, effective judicial redress is warranted for each individual case. In fact, it is a requirement which holds the rank of constitutional law (Article 13 of the European Convention on Human Rights; Article 47 of the EU Charter of Fundamental Rights). Courts, however, will generally be hesitant to keep track of an agency's general implementation of policies.

As with political accountability, the shared legal order of the EU poses interesting questions with respect to the cooperation between the courts at EU level and national courts (vertical dimension), and - although this is not always addressed in this book's case studies - the relationships and division of labour between different national courts (horizontal dimension).

The relationships between judicial and political accountability are, however, not always clear-cut. Some types of actions and/or decisions, such as the choice not to investigate a suspicious case or to investigate in a particular national jurisdiction, may fall within a grey area. Which type of accountability is or should be there in such a case? On the one hand, the decision not to investigate a particular company may affect other (competing) companies, which raises the question of whether the latter could and should be able to question such a decision by an enforcement authority in the courts. On the other hand, and especially if no judicial redress is possible, one may wonder to what extent political accountability could and should play a role here (filling in a possible judicial accountability gap). The decision not to investigate a case or to investigate it in jurisdiction A and not jurisdiction B may fall within an executive discretion given to an EEA and/or NEA by law to enforce EU law effectively.

Two questions arise in this respect. Should this decision fall within executive discretion protected possibly by the independent status of an EEA and/or NEA and thus be free from control by politicians? Alternatively, should the EEA and/or NEA render account for this choice and perhaps even issue (internal) general guidelines on which cases could be dropped and which have to be investigated and where, though, for instance, its annual report? Would it be an accountability gap if both judicial and

Tasks and Power of the Prosecution Services in the EU Member States (vol 1 Wolf 2004); P Tak (ed.), Tasks and Powers of the Prosecution Services in the EU Member States (vol 2 Wolf 2005); M Zwiers, The European Public Prosecutor - Analysis of a Multilevel Criminal Justice System (Intersentia 2011). 
political accountability were not envisaged here? Would it be accountability redundancy, eventually causing ineffectiveness of law enforcement, if both types of accountability were present?

\subsubsection{Accountability in a shared legal order}

Before we embark on an explanation of the design of the case studies, there remains one final remark to be made on the approach of this study. As already said, the approach of this book hinges upon two axes. It deals with the relationships between the political and judicial forms of accountability, as well as the relationships between the national and the EU levels. In the shared legal order of the EU, the accountability for how investigative, prosecutorial and sanctioning discretion has been given shape in specific policy lines is closely linked to the division of work between the national levels and EU level (the vertical dimension), as well as - where relevant - between the various national legal orders involved (the horizontal dimension).

There is literature on the advantages and disadvantages of multiplicity of actors and forums for accountability, although with no clear consensus on these issues. Scott and Mulgan stress the advantages of having overlapping accountability mechanisms, which create a 'redundancy safeguard' against the absence of any control, and of having different facets scrutinized by different accountability forums. ${ }^{30}$ The disadvantages have been identified with free riding, which may reduce the collective capacity of exerting control over the 'agent', ${ }^{31}$ and 'multiple accountabilities disorder', i.e., situations where conflicting accountability expectations undermine the effectiveness of the organization that is supposed to be held accountable. ${ }^{32}$ Papadopoulos expressed a number of concerns regarding the consequences of the multiplication of control mechanisms, in relation to both the efficiency and democratic quality of a given regulatory regime, including the problems of 'too many eyes', information overloads, and reduced transparency. ${ }^{33}$ Brandsma pointed out a solution in this regard:

30 R Mulgan, Holding Power to Account: Accountability in Modern Democracies (Palgrave Macmillan 2003); C Scott, 'Accountability in the Regulatory State' (2000) 27 Journal of Law and Society 38.

31 T Besley and M Ghatak, 'Incentives, Choice, and Accountability in the Provision of Public Services' (2003) 19 Oxford Review of Economic Policy 235; S Gailmard, 'Multiple Principals and Oversight of Bureaucratic Policy-Making' (2009) 21 Journal of Theoretical Politics 161.

32 J Koppell, 'Pathologies of Accountability: ICANN and the Challenge of "Multiple Accountabilities Disorder"” (2005) 65 Public Administration Review 94.

33 Y Papadopoulos, 'Accountability and Multi-level Governance: More Accountability, Less Democracy?', (2010) 5 West European Politics 1040-41. 
accountability at the macro-level should be understood as the aggregation of all individual accountability relations. ${ }^{34}$

The system of shared enforcement in the EU seems to bring another, so far underestimated, challenge to accountability, i.e. the possible inability of an accountability forum (EU or national) to hold its actor (EU or national respectively) to account due to the multilevel setting of law enforcement. The inability could be caused by the impossibility of getting access to the necessary (preparatory) documents and actors in the (beginning) stages of the enforcement process performed at the other (national/EU) level. ${ }^{35}$ Here, a separation of accountability forums between the EU and national levels may negatively affect the ability of, for instance, a national accountability forum to hold the NEA to account because the NEA may have performed tasks or may have taken decisions based on information or instructions from an EEA. Standing before the national accountability forum, the NEA could point the finger at the EEA and if the national accountability forum has no possibility of getting access to the EEA (and its documents) or of requesting necessary assistance from the relevant EU accountability forum, the accountability of the NEA and perhaps even of the whole (enforcement) process may be doomed.

As far as accountability for the whole enforcement process is concerned, the problem that 'the sum is more than its parts' may arise. If the enforcement process is shared in a fully complementary way between an EEA and NEA in the sense that the enforcement process is performed at EU or national level, the question becomes, who is accountable for enforcement in a particular sector in general and before whom/at what level? If it is the actor who takes the final decision, it seems necessary to ensure that he or she has the power to control those whose actions and (preliminary) decisions he or she takes over. If the actor does not have that power, then the problem may be that he or she may be held to account for something he or she did not do and those responsible could escape responsibility since their actions were not 'final' or 'binding', which could affect, if not refute, for instance, judicial accountability. Judicial accountability is invoked if the legal position of a private actor is affected; this usually presupposes a final or legally binding act.

34 G Brandsma, Controlling Comitology: Accountability in a Multi-level System (Palgrave Macmillan 2013) 42-62.

${ }_{35}$ M Eliantonio, 'Judicial Review in an Integrated Administration: The Case of "composite procedures" (2015) 7 Review of European Administrative Law 65. 


\section{SCIENTIFIC STATE OF THE ART AND THE ASPIRATIONS OF THIS BOOK}

We believe that this book comes at precisely the right time. From a societal perspective, there is the obvious tension between the lack and pitfalls of law enforcement by national authorities when attempting to address the common EU problems of the day and the increasing focus on the nation state, which is one of the main reasons why most - if not all - EU authorities operate on the basis of a decentralized (fragmented, if one is more critical) framework. This causes all sorts of accountability problems. In addition, from an academic perspective, existing studies on accountability, judicial protection and enforcement by EU authorities have not yet been linked up. The existing scholarship on EU policy-making and actors, including EU agencies, has focused largely on the regulation, transposition and implementation (rather than EU (shared) enforcement) stages of the EU policy cycle; ${ }^{36}$ transnational criminal law enforcement ${ }^{37}$

36 I Kissling-Näf and S Wälti, 'The Implementation of Public Policies' in U Klöti and others (eds), Handbook of Swiss Politics (2nd edn, NZZ 2012) 501-24; C Knill, K Schulze and J Tosun, 'Regulatory Policy Outputs and Impacts: Exploring a Complex Relationship' (2012) 6 Regulation and Governance 427; L Senden, 'Soft Post-legislative Rulemaking in the EU: A Time for More Stringent Control' (2013) 19 European Law Journal 57; Bernard Steunenberg, 'A Policy Solution to the European Union's Transposition Puzzle: Interaction of Interests in Different Domestic Arenas' (2007) 30 West European Politics 23; M Thatcher and D Coen, 'Reshaping European Regulatory Space: An Evolutionary Analysis' (2008) 31 West European Politics 806; E Thomann, 'Customizing Europe: Transposition as Bottom-up Implementation' (2015) 22 Journal of European Public Policy 1368; D Toshkov, 'Taking Stock: A Review of Quantitative Studies of Transposition and Implementation of EU Law' (2010) Institute for European Integration Research Working Paper 01/2010, <https:/eif.univie.ac.at/downloads/workingpa pers/wp2010-01.pdf> accessed 13 December 2016; E Versluis, 'Even Rules, Uneven Practices: Opening the "Black Box" of EU Law in Action' (2007) 30 West European Politics 50; E Versluis, 'Enforcement Matters. Enforcement and Compliance of European Directives in Four Member States' (Doctoral thesis Utrecht University, Eburon 2003).

37 L Bachmaier Winter, 'Transnational Criminal Proceedings, Witness Evidence and Confrontation: Lessons from the ECtHR's Case Law' (2013) 9 Utrecht Law Review 127; C Claverie-Rousset, 'The Admissibility of Evidence in Criminal Proceedings between European Union Member States' (2013) 3 European Criminal Law Review 152; M Luchtman, European Cooperation between Financial Supervisory Authorities, Tax Authorities and Judicial Authorities (Intersentia 2008); J Vervaele, 'The European Union and Harmonization of the Criminal Law Enforcement of Union Policies: In Search of a Criminal Law Policy?' in M Ulväng and I Cameron (eds), Essays on Criminalization and Sanctions (Iustus förlag 2014) 185-225; J Vervaele, 'Union Law and Harmonisation of National Economic and 
and control of regulatory tasks. ${ }^{38}$ The multidisciplinary scholarship on accountability has focused mainly on (political) accountability or judicial protection in the EU. ${ }^{39}$ Hardly any research attention has been paid to the questions of interplay between accountability types, i.e. when which type of accountability is appropriate, on what conditions, and for what purposes..$^{40}$

So far as the state of the art is concerned, we aim to contribute to the debate by gathering and comparing the data from all the relevant policy areas, particularly with respect to the following issues:

(1) a comparative study of judicial accountability in a shared system of EU law enforcement, with a view to identifying gaps and unnecessary duplications, but also potential best practice;

(2) a comparative study of political accountability in a shared system of EU law enforcement, with a view to identifying gaps and unnecessary duplications, but also potential best practice;

(3) a comparative study of the relationships between the two forms of accountability in such a shared system, both in terms of the ability of the two forms to compensate for shortcomings of the other, and to avoid duplications.

\section{METHODOLOGICAL CONSIDERATIONS}

From a normative perspective, our departure point is that enforcement, whether arranged at the EU or national level, or as a shared activity, involves the use of public authority. This leads to the need for public

Financial Criminal Law' in E Bleichrodt, A Hartmann, P Mevis, R Lodewijk and B Salverda (eds), Onbegrensd strafrecht - Liber Amicorum Hans de Doelder (Wolf Legal Publishers 2014) 143-55; cf Ligeti and Simonato (n 25); Zwiers (n 29).

38 E Vos, 'Independence, Accountability and Transparency of European Regulatory Agencies' in D Geradin, R Muňoz and N Petit (eds), Regulation through Agencies in the EU: A New Paradigm of European Governance (Edward Elgar Publishing 2005) 120-40; M Busuioc, The Accountability of European Agencies: Legal Provisions and Ongoing Practices (Eburon 2010).

39 Busuioc (n 38); S Lavrijssen, 'What Role for Administrative Courts in Granting Effective Legal Protection in the Energy Sector?' (2014) 23 European Energy and Environmental Law Review 219; but see: Hofmann, Rowe and Türk (n 6).

40 M Bovens and T Schillemans, 'Meaningful Accountability' in M Bovens, R Goodin and T Schillemans (eds), The Oxford Handbook of Public Accountability (OUP 2014) 672-82. 
accountability - the check of the governors by the governed. Depending on the statutory remit, which defines the tasks and powers of EEAs and NEAs, there will be a need for political and judicial accountability to ensure democratic control and the rule of law. In this project we focus more specifically on the decisions and actions during the three stages of enforcement: monitoring, investigating and sanctioning. Such actions and/or decisions concern mainly determining (parts of) enforcement policies, including forum choices and settlement; opening investigations; passing specific investigative acts; and imposing sanctions in a wide sense, including supervisory measures like a public notice but also monetary fines. Thus, the research focus has been on how the political and judicial accountability regimes relate to these four types of actions/decisions.

\subsection{Analytical Framework}

Based on what can we conclude whether or not an EEA and/or an NEA is politically and judicially accountable? Our analytical framework departs from the three stages of accountability distinguished by Bovens information, discussion and rectification. ${ }^{41}$ While the activation of political accountability mechanisms depends on the strength and willingness of political 'principals', the de jure analysis of political accountability is based on the presence of mechanisms allowing these stages:

- information stage - (annual) reporting and other requests for information related to law enforcement policies and instructions;

- discussion stage - regular and ad hoc questioning during (parliamentary) hearings and relevant meetings;

- rectification stage - financial and functional reductions or increases of budgets and powers, blaming and shaming and reappointment and removal of the top-level officials.

While these stages allow political accountability mechanisms to be analysed, this is less so in the case of judicial accountability. This is because the activation of judicial accountability mechanisms depends on the strength of those affected by the enforcement of agencies' decisions. Judicial accountability is exercised via judicial review of enforcement decisions. ${ }^{42}$

41 Bovens (n 6); Mulgan (n 30); M Scholten, The Political Accountability of EU and US Independent Regulatory Agencies (Brill Nijhoff 2014).

42 P Craig, 'Shared Administration, Disbursement of Community Funds and the Regulatory State in Legal Challenges' in Hofmann, Rowe and Türk (n 14) 34-62. 
While, strictly speaking, the court is an accountability forum before which an enforcement authority renders account, judicial accountability requires a party concerned to trigger it; the courts do not review enforcement decisions in abstracto. To this end, to analyse and assess judicial accountability, we need to expand this framework with elements allowing private actors to trigger judicial accountability - access to the court by the parties concerned and the possibility for the court to review an act brought before it. Only then, could the three stages of Bovens be investigated - the obligation of enforcement authorities to provide information to and to justify their actions in the court and the existence of effective judicial remedies to rectify the breach of law. Our analysis of judicial accountability is thus also based on investigating those additional elements, which together form the legal principle of effective judicial protection. ${ }^{43}$

This assessment exercise is fruitful because it can determine undesirable gaps and/or redundancies with a view to attempting to address them. The existing research on accountability has made it clear that sources of accountability problems may come from (1) the lack or poor formulation of accountability mechanisms in law and/or (2) the selective or improper exercise of accountability mechanisms in reality. ${ }^{44}$ So far as the former are concerned, the quantity and quality of accountability mechanisms prescribed by law can be affected by the design of EEAs and/or NEAs more specifically their independence - that can be explained by functional necessities, especially in the field of enforcement, and the politics of the negotiation process. ${ }^{45}$ Therefore, it is essential that the legal designs of accountability and of independence are considered and balanced with each other. As for the latter, the problems of the actual exercise of accountability mechanisms are interconnected with information/knowledge asymmetry and the salience of an agency or the policy area which the agency supervises; this results in selectivity, if not at times, absence of political accountability.

So far as the aspects that could limit accountability are concerned, we have considered the issues of independence and confidentiality clauses.

43 Jans, Prechal and Widdershoven (n 2); P Craig 'Formal and Substantive Conceptions of the Rule of Law: An Analytical Framework' (1997) Public Law 467.

44 Among the most recent works on agencies, e.g. Scholten (n 41); Busuioc (n 38).

45 M Groenleer, The Autonomy of European Union Agencies (Eburon 2009); F Gilardi, 'Policy Credibility and Delegation to Independent Regulatory Agencies: A Comparative Empirical Analysis' (2002) 9 Journal of European Public Policy 873. 
To make sensible use of discretion, an EEA or NEA should be protected from interference by politicians and the industry, especially when it comes to taking such decisions as opening or not opening an investigation into an alleged violation of law and what punishment should be imposed. Protecting functional discretion can be achieved by making an EEA or NEA institutionally separate from the parent executive institution, granting it a separate (from the executive) budget or making it self-funded, and/ or making the (re)appointment and/or removal procedures of relevant top officials subject to certain safeguards (e.g. the removal 'for cause' clause). ${ }^{46}$ These institutional, financial and personal elements of independence have become the focus in our analysis; they promote functional discretion, i.e. reduce the possibility for, e.g. politicians to influence enforcement actions or decisions of EEAs or NEAs. However, these elements may also affect accountability. ${ }^{47}$ They can quantitatively reduce the accountability arsenal of parliaments and courts (in comparison with that of the main executive) and influence the 'quality'/substance of accountability relations. For instance, making an EEA or NEA self-funded implies that it would escape financial accountability before the parliament; this is a venue, however, where the members of parliament could check as well as influence such issues as enforcement policy priorities via allocating (or not) financial means to specific areas. While recent research has provided some support to the hypothesis that independence can actually co-exist with accountability - understood as a system of ex-post controls - the challenge is to find the appropriate accountability mechanisms that do not conflict with the supposed gains in terms of credibility and efficiency of regulation that are expected to emanate from agencies' independence. ${ }^{48}$ Finally, the substance of an accountability relation can be restricted by confidentiality

46 M Scholten, 'Independence vs. Accountability: Proving the Negative Correlation' (2014) 21 Maastricht Journal Of European And Comparative Law 197.

47 The literature on the regulatory state typically assumes not only the possibility of reconciling the independence and accountability of agencies, but also that their greater independence would go along with greater accountability: G Majone, Regulating Europe (Routledge 1996). In theory, this could be achieved through a 'multipronged' system of controls, where no one directly controls the agency, yet the agency is ultimately under control: T Moe, 'Interests, Institutions, and Positive Theory: The Politics of the NLRB' (1987) 2 Studies in American Political Development 236. The crucial problem is to find the appropriate accountability mechanisms that do not conflict with the supposed gains in terms of credibility and efficiency of regulation that are expected to derive from agencies' independence: M Maggetti, 'Legitimacy and Accountability of Independent Regulatory Agencies: A Critical Review' (2010) 2 Living Reviews in Democracy 1.

48 Maggetti, ibid.; Busuioc (n 24). 
clauses, which seems especially relevant in relation to law enforcement which lies closely alongside the rights and freedoms of private actors involved in individual investigations. Confidentiality affects the access to information and the discussion of it in both the court and the parliament.

Therefore, it is essential to discuss the elements of independence protecting functional discretion and confidentiality clauses in assessing the accountability of EEAs and/or NEAs in order to explain any possible low number and restricted scope of accountability mechanisms or even the absence of such mechanisms. ${ }^{49}$ This explanation will help to distil the source of a possible accountability problem - is an EEA and/or NEA less accountable because of its independence which ensures the ability to exercise functional discretion? If the source of the accountability problem lies outside independence or problematic accountability 'in action', in light of the focus of this volume, the aim has been to see whether (and to what extent) the 'sharedness' of law enforcement in the EU causes undesirable gaps or redundancies in accountability.

\subsection{Method and Sub-Questions}

This book focuses on the questions concerning to what extent the shift of direct enforcement powers to the EU has been accompanied by ensuring political and judicial accountability systems, including at what level (EU or national), and how political and judicial accountability interact in relation to enforcement. To address these questions, we have first conducted an inquiry into the EU actors in all policy areas to identify the scope of this phenomenon, i.e., how many EEAs are there? (see Annex below). Having identified the eight EEAs and the ongoing discussion on the creation of EPPO, the legal frameworks of each of the existing EEAs in conjunction with relevant NEAs have been analysed by individuals or groups of researchers-experts in the field. The following questions, which correspond to the sections of individual chapters, have been addressed:

1. Who are the relevant actors (EEA/NEA(s)) in the particular sector affected by shared enforcement in the EU? Which NEAs are relevant to be considered in the case study? The project as a whole has taken no specific national jurisdiction on board. Rather, each case study has selected relevant national authorities to demonstrate and to analyse shared enforcement in a particular sector. This is because the specifics of the field within which an EEA operates influence the relevance

\footnotetext{
49 Gilardi (n 45).
} 
of national jurisdictions; it does not make sense to consider the Netherlands in the case of ESMA as no credit rating agency or trade repository, i.e. the entities under ESMA's supervision, exists in the Netherlands. As the majority of these entities (including the biggest ones) are situated in London, which implies that enforcement will take place there, the UK was the natural choice for that particular case study. Thus, the selection of national jurisdictions has been dictated by mainly substantive reasons, including consideration of the following criteria as well: significance and size of specific markets for the national jurisdictions; possible differences in enforcement strategies, which could make it necessary to take jurisdictions representing the 'families' of specific enforcement styles; and specific legal features of national jurisdictions, such as common law, if this mattered for a specific case.

2. Who does what in the shared enforcement? What is shared in enforcement and how? As this subject has hardly been investigated at all until now, the authors of the case studies have been trying to dig into the system and show what shared enforcement means in each of these cases. The focus has been on both institutional and substantive areas, including addressing such issues as: institutional design of EEAs and relevant NEAs; their tasks in general and enforcement tasks in particular; the relationship between EEAs and NEAs in terms of sharing, dividing or subordinating powers and tasks among themselves; and the types of actions and decisions that relevant actors can take for which accountability would be necessary (e.g. power to develop enforcement policies, decisions to open investigation, investigative acts interfering with fundamental rights, decision to impose a sanction).

3. How is the system of political and judicial accountability organized in the system of shared enforcement in the given case? The analysis of political and judicial accountability has been provided in light of the analytical framework established earlier in this section. The focus has been on accountability for specific actions and decisions and the necessity of a specific type of accountability for those actions and decisions to understand the interaction between political and judicial accountability.

4. What are the gaps/redundancies in the system of accountability and their sources and how could the gaps/redundancies be addressed? The authors of each case study were asked to conclude with showing potential or existing inconsistencies of political and/or judicial accountability, which could undermine the core values of democracy and the rule of law and how these could be addressed. 
Secondly, based on the comprehensive overview of the system of shared enforcement in all the existing comparative insights from the case studies, four cross-cutting studies have been conducted to compare and analyse the implications for accountability of the 'verticalization' of enforcement in the EU from their four specific perspectives. The need to look into these four perspectives has been in part highlighted by the preliminary results of the case studies discussed at the two meetings of all the participants of the project (on 26 February and 1 September 2016 in Utrecht). These perspectives comprise the substantive meaning of accountability, the role of the European Court of Auditors as an accountability forum, the issues of judicial protection in the shared enforcement and the overall comparison of the results.

\section{THIS VOLUME AND ITS CONTRIBUTION}

This edited volume is a collection of works written and discussed by 30 international academics and practitioners with one common aim. It is to put the quite recent yet rapidly growing phenomenon of shared enforcement in the EU on the map and to offer a critical analysis of the implications of this development in terms of accountability. Ensuring democratic control and the rule of law are essential, especially in such a contested context as the EU. In addition to generating new and comprehensive knowledge on this development and its scope, we believe that our contribution has been twofold.

First, for academics and researchers in general, we have offered a new analytical framework on how accountability could be investigated in a more comprehensive way. This has been made possible by combining the analytical framework on accountability from public administration scholars (following such scholars as Bovens, Mulgan and Papadopoulos) with the legal principle of effective judicial protection, developed largely by legal scholars. Using one or the other would not have enabled us to produce the same comprehensive result. By making this first attempt of combining political and judicial accountability, we have launched the discussion on the need in accountability research to move beyond the identification of challenges towards the analysis and design of which type of accountability is appropriate, on what conditions, and for what purposes. ${ }^{50}$ In addition, this has been done in relation to the expanding administration of shared enforcement in the EU, which in itself is also a relatively new and understudied phenomenon.

50 Bovens and Schillemans (n 40). 
Second, we believe that the book provides a valuable contribution for various groups of society, including practitioners, i.e. officials from the EEAs and their national counterparts, judges, politicians and civil servants; stakeholders, i.e. private actors, which could be subject to enforcement procedures by EEAs and NEAs in the shared enforcement setting, and clearly the citizen. This volume provides information on relevant procedures and legal regimes in specific sectors of the economy and also relates to individual EEAs and NEAs. It highlights points for attention, which we recommend that practitioners and stakeholders should address together in order to respect democratic control and the rule of law.

The book proceeds as follows. Chapters 2-10 give an in-depth analysis of the system of shared enforcement by scrutinizing individual EEAs and, where necessary, one or more relevant NEAs. The order of these chapters corresponds to the descending strength of enforcement powers of EEAs and, where relevant, to the relevance of the sectors in which EEAs operate.

So, we start with the strongest three (first the two financial supervisors ECB and ESMA and then the Commission's DG COMP), continue with those EEAs which closely collaborate with the Commission (ordered among themselves again in terms of their powers) and conclude with an EEA whose establishment is under discussion at this moment (EPPO). The chapter by Ton Duijkersloot, Argyro Karagianni and Robert Kraaijeveld starts off the discussion by looking at political and judicial accountability in the EU shared system of banking supervision and enforcement (Chapter 2). They focus on the very powerful institution, the European Central Bank and its Dutch and Greek counterparts. Marloes van Rijsbergen and Jonathan Foster analyse the political and judicial accountability of the European Securities and Markets Authority's enforcement powers (Chapter 3); this is the strongest of the EU agencies and the only one with direct enforcement powers. As mentioned earlier, their selected national jurisdiction has been the UK and its Financial Conduct Authority. Katalin Cseres and Annalies Outhuijse zoom in on the area of EU competition law enforced by the Commission's Directorate-General for Competition, Dutch and Hungarian competition authorities as well as an additional structure, namely the European Competition Network (Chapter 4). Florin Coman-Kund, Mikołaj Ratajczyk and Elmar Schmidt continue the discussion of shared enforcement and accountability in the Aviation Safety Area by analysing the growing powers of the European Aviation Safety Agency and its French and German counterparts (Chapter 5). Merijn Chamon and Sabrina Wirtz present a case of what they call a 'modest start' of the verticalization of enforcement in pharmacovigilance and its implications for accountability. They focus on the European Medicines Agency and relevant Belgian and German authorities (Chapter 6). Federica Cacciatore 
and Mariolina Eliantonio analyse the accountability of the European Fisheries Control Agency, an EEA with a limited inspection powers, and its UK and Italian counterparts in enforcing the common fisheries policy of the EU (Chapter 7). Antonia Corini, Bernd van der Meulen, Floris Kets, Giuseppa Ottimofiore and Florintin Blanc add to the discussion by showing the emergency powers of the Commission's Directorate-F in the field of direct enforcement of EU food law and the challenges, which such powers bring for accountability (Chapter 8). They take the Dutch and Italian jurisdictions on board for comparison. Michiel Luchtman and Martin Wasmeier scrutinize the political and judicial accountability of OLAF (the European Anti-Fraud Office), an independent part of the Commission with fragmented investigative powers, and its Dutch counterpart (Chapter 9). John Vervaele concludes the analysis of individual case studies with a chapter on accountability for criminal investigations and prosecutions by a European Public Prosecutor's Office in the EU, an EEA which does not exist but whose creation is being intensely debated at this moment by legislatures across the EU (Chapter 10).

Chapters 11-14 offer a cross-cutting analysis on the four issues. Florentin Blanc and Giuseppa Ottimofiore take a critical look at the formulation of accountability obligations of EEAs and how these affect the meaning of rendering and holding to account (Chapter 11). They discuss the lessons that we could draw from other sectors in this respect. Alex Brenninkmeijer and Emma van Gelder analyse the role of the European Court of Auditors (ECA) in holding EEAs to account, because we notice that the ECA has proved quite effective for reinforcing political or judicial accountability (Chapter 12). Rob Widdershoven and Paul Craig zoom in on one of the pertinent implications of the system of shared enforcement in the EU - that of ensuring judicial protection, and the existing possibilities and challenges (Chapter 13). Miroslava Scholten, Martino Maggetti and Esther Versluis conclude the book with the discussion of the political and judicial accountability in the shared enforcement in the EU by addressing the main research questions based on comparative insights of all the contributions (Chapter 14). In a way, at the meta-level, the order of Chapters 2-10 corresponds to the observations of this concluding chapter that, while the overall degree of accountability of EEAs is not very high and improvements are needed, a correlation between the strength of powers and availability of accountability mechanisms at the EU level can be detected. 


\section{ANNEX}

In order to identify the European Enforcement Authorities (EEAs) and their characteristic direct enforcement powers, all (to our knowledge) EU institutions, networks and agencies were studied. Table 1A.1 below lists them according to the policy area to which they belong. The policy areas are listed in alphabetical order and specify the competence - exclusive, shared or supporting - of the EU in each of these. The policy areas are broken down into sub-groups in order to indicate the field in which the relevant institution, agency or network operates. From this list, the EEAs were identified. The EEAs, of which there are eight in total, are marked grey in the table and are accompanied by a brief description of which of the three enforcement powers they possess (monitoring, investigation and/or sanctioning). The relevant chapters on the EEAs featured in this book peruse their direct enforcement powers in more detail, along with the applicable accountability mechanisms. Under the name of each of the subjects in the table, in the column 'EU Entities', a specification of the legislative documents that were examined in order to determine the presence of direct enforcement powers is included.

\section{Table 1A.1 Justification of the case selection (EEAS)}

\begin{tabular}{|c|c|c|c|}
\hline $\begin{array}{l}\text { Policy Area } \\
\text { Allocation of } \\
\text { powers } \\
\text { (alphabetically) }\end{array}$ & Sub-group & $\begin{array}{l}\text { EU entities } \\
\text { Reviewed legislation }\end{array}$ & $\begin{array}{l}\begin{array}{l}\text { Direct } \\
\text { enforcement } \\
\text { powers (yes/no): }\end{array} \\
\text { Type of } \\
\text { enforcement } \\
\text { powers }\end{array}$ \\
\hline \multirow{3}{*}{$\begin{array}{l}\text { 1. Agriculture, } \\
\text { Food \& } \\
\text { Fisheries } \\
\text { (excluding } \\
\text { the } \\
\text { conservation } \\
\text { of marine } \\
\text { biological } \\
\text { resources) } \\
\text { (shared) }\end{array}$} & Food Fraud & $\begin{array}{l}\text { Directorate F } \\
-\quad \text { Regulation No 882/2004 } \\
-\quad \text { Regulation No 178/2002 }\end{array}$ & $\begin{array}{l}\text { Yes: } \\
\text { Monitoring and } \\
\text { investagation } \\
\text { powers }\end{array}$ \\
\hline & Food Safety & $\begin{array}{l}\text { European Food Safety Authority } \\
\text { (EFSA) } \\
-\quad \text { Regulation No } 178 / 2002\end{array}$ & No \\
\hline & Fisheries & 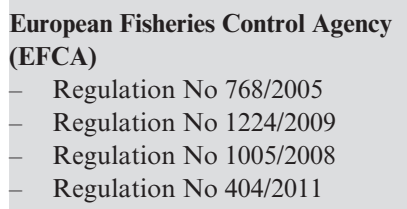 & $\begin{array}{l}\text { Yes: } \\
\text { Investigation } \\
\text { powers }\end{array}$ \\
\hline $\begin{array}{l}\text { 2. Area of } \\
\text { Freedom, } \\
\text { Security \& }\end{array}$ & Asylum & $\begin{array}{l}\text { European Asylum Support Office } \\
\text { (EASO) } \\
-\quad \text { Regulation No } 439 / 2010\end{array}$ & No \\
\hline
\end{tabular}




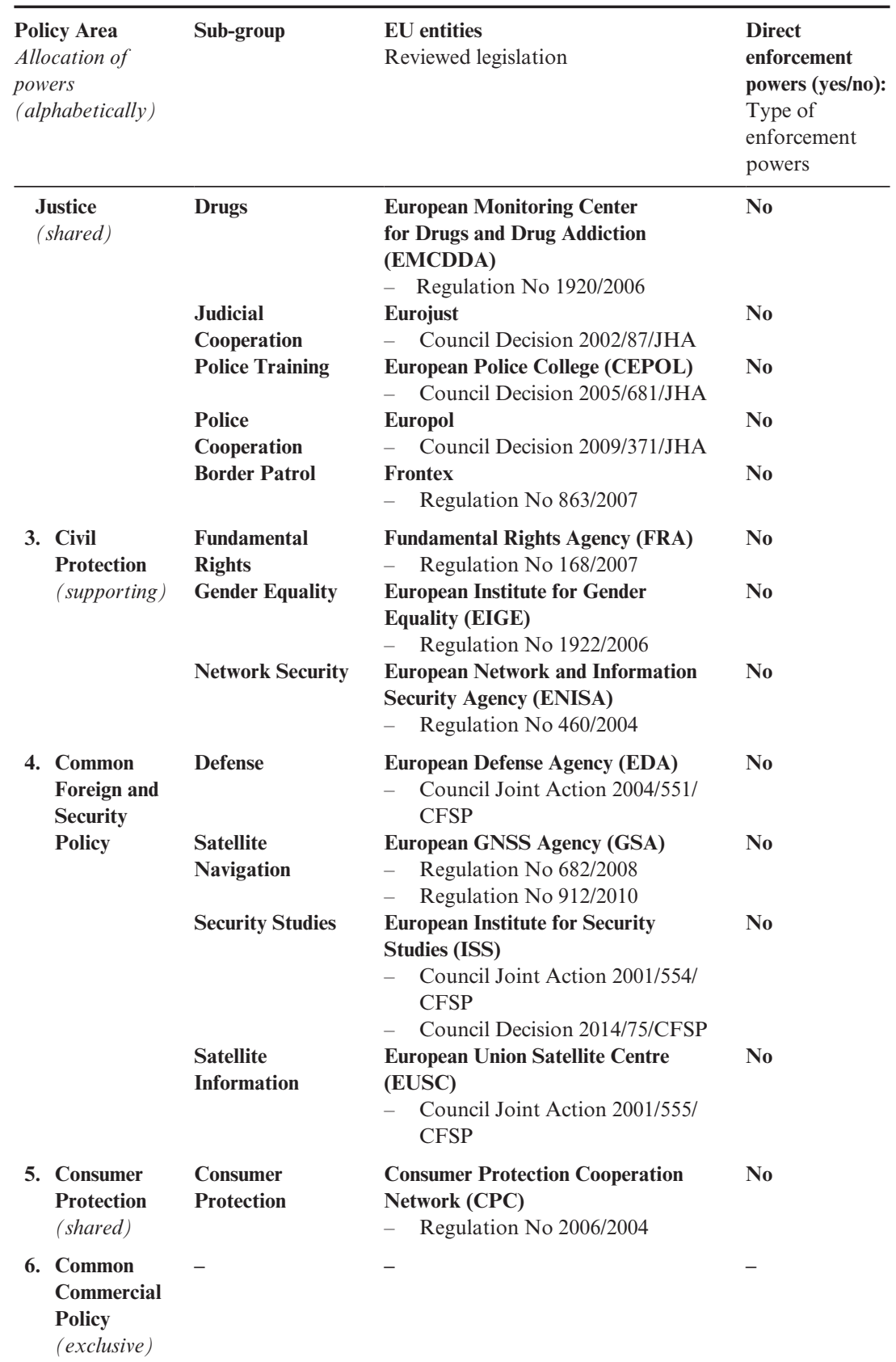


Table 1A.1 (continued)

\begin{tabular}{|c|c|c|c|}
\hline $\begin{array}{l}\text { Policy Area } \\
\text { Allocation of } \\
\text { powers } \\
\text { (alphabetically) }\end{array}$ & Sub-group & $\begin{array}{l}\text { EU entities } \\
\text { Reviewed legislation }\end{array}$ & $\begin{array}{l}\text { Direct } \\
\text { enforcement } \\
\text { powers (yes/no): } \\
\text { Type of } \\
\text { enforcement } \\
\text { powers }\end{array}$ \\
\hline $\begin{array}{l}\text { 7. Competition } \\
\text { (exclusive) }\end{array}$ & Competition & $\begin{array}{l}\text { European Commission } \\
-\quad \text { Title VII TFEU } \\
-\quad \text { Regulation No } 1 / 2003 \\
\text { European Competition Network } \\
-\quad \text { Commission Notice on } \\
\quad \text { cooperation within the Network } \\
\quad \text { of Competition Authorities }\end{array}$ & $\begin{array}{l}\text { Yes: } \\
\text { Monitoring, } \\
\text { investigation } \\
\text { and sanctioning } \\
\text { powers } \\
\text { No }\end{array}$ \\
\hline \multirow{2}{*}{$\begin{array}{l}\text { 8. Education, } \\
\text { Vocational } \\
\text { Training, } \\
\text { Youth and } \\
\text { Sport } \\
\text { (supporting) }\end{array}$} & $\begin{array}{l}\text { Education, } \\
\text { Vocational }\end{array}$ & $\begin{array}{l}\text { ETF (CEDEFOP Sister agency) } \\
-\quad \text { Regulation No } 1339 / 2008\end{array}$ & No \\
\hline & $\begin{array}{l}\text { Training, Youth } \\
\text { and Sport } \\
\text { Education, } \\
\text { Vocational } \\
\text { Training, Youth } \\
\text { and Sport }\end{array}$ & $\begin{array}{l}\text { CEDEFOP (ETF Sister agency) } \\
-\quad \text { Regulation No } 337 / 75\end{array}$ & No \\
\hline $\begin{array}{l}\text { 9. Energy } \\
\text { (shared) }\end{array}$ & Energy & 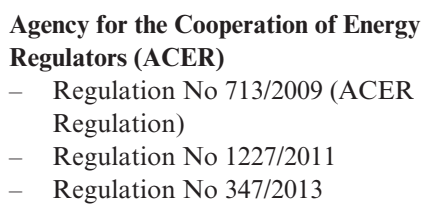 & No \\
\hline $\begin{array}{l}\text { 10. Environment } \\
\text { (shared) }\end{array}$ & Environment & $\begin{array}{l}\text { European Environment Agency (EEA) } \\
-\quad \text { Regulation No } 401 / 2009\end{array}$ & No \\
\hline \multirow[t]{5}{*}{$\begin{array}{l}\text { 11. Internal } \\
\text { Market } \\
\text { (shared) }\end{array}$} & $\begin{array}{l}\text { Electronic } \\
\text { Communications }\end{array}$ & $\begin{array}{l}\text { Body of European Regulators for } \\
\text { Electronic Communication (BEREC) } \\
-\quad \text { Regulation No 1211/2009 }\end{array}$ & No \\
\hline & Financial Markets & $\begin{array}{l}\text { European Banking Authority (EBA) } \\
-\quad \text { Regulation No 1093/2010 }\end{array}$ & No \\
\hline & Financial Markets & $\begin{array}{l}\text { European Insurance and Occupational } \\
\text { Pensions Authority (EIOPA) } \\
-\quad \text { Regulation No 1094/2010 }\end{array}$ & No \\
\hline & Financial Markets & $\begin{array}{l}\text { European Securities and Markets } \\
\text { Authority (ESMA) } \\
-\quad \text { Regulation No 1095/2010 } \\
-\quad \text { Regulation No 1060/2009 }\end{array}$ & $\begin{array}{l}\text { Yes: } \\
\text { Monitoring, } \\
\text { investigation } \\
\text { and sanctioning } \\
\text { powers }\end{array}$ \\
\hline & Financial Markets & $\begin{array}{l}\begin{array}{l}\text { European Systemic Risk Board } \\
\text { (ESRB) } \\
-\quad \text { Regulation No } 1092 / 2010\end{array}\end{array}$ & No \\
\hline
\end{tabular}




\begin{tabular}{|c|c|c|c|}
\hline $\begin{array}{l}\text { Policy Area } \\
\text { Allocation of } \\
\text { powers } \\
\text { (alphabetically) }\end{array}$ & Sub-group & $\begin{array}{l}\text { EU entities } \\
\text { Reviewed legislation }\end{array}$ & $\begin{array}{l}\text { Direct } \\
\text { enforcement } \\
\text { powers (yes/no): } \\
\text { Type of enforce- } \\
\text { ment powers }\end{array}$ \\
\hline & $\begin{array}{l}\text { Intellectual } \\
\text { Property }\end{array}$ & $\begin{array}{l}\text { Office for Harmonization in the } \\
\text { Internal Market (OHIM) } \\
\text { - Regulation No 207/2009 }\end{array}$ & No \\
\hline & $\begin{array}{l}\text { Intellectual } \\
\text { Property }\end{array}$ & $\begin{array}{l}\text { Community Plant Variety Office } \\
\text { (CPVO) } \\
\text { - Regulation No } 2100 / 94\end{array}$ & No \\
\hline $\begin{array}{l}\text { 12. Industry } \\
\text { (supporting) }\end{array}$ & $\begin{array}{l}\text { Chemical } \\
\text { Substances } \\
\text { No direct } \\
\text { enforcement } \\
\text { powers }\end{array}$ & $\begin{array}{l}\text { European Chemical Agency (ECHA) } \\
\text { - Regulation No 1907/2006 }\end{array}$ & No \\
\hline $\begin{array}{l}\text { 13. Monetary } \\
\text { Policy } \\
\text { (exclusive) }\end{array}$ & $\begin{array}{l}\text { Banking } \\
\text { Supervision }\end{array}$ & $\begin{array}{l}\text { European Central Bank (ECB) } \\
\text { - Protocol on the Statute of the } \\
\text { European System of Central } \\
\text { Banks and of the } \\
\text { - Regulation No } 1024 / 2013 \\
\text { - Regulation No } 2532 / 98\end{array}$ & $\begin{array}{l}\text { Yes: } \\
\text { Monitoring, } \\
\text { investigation } \\
\text { and sanctioning } \\
\text { powers }\end{array}$ \\
\hline \multirow{3}{*}{$\begin{array}{l}\text { 14. Protection } \\
\text { and } \\
\text { Improvement } \\
\text { of Human } \\
\text { Health } \\
\text { (supporting) }\end{array}$} & $\begin{array}{l}\text { Disease Prevention } \\
\text { and Control }\end{array}$ & $\begin{array}{l}\text { European Center for Disease } \\
\text { Prevention and Control (ECDC) } \\
\text { - Regulation No 851/2004 }\end{array}$ & No \\
\hline & Medicines & $\begin{array}{l}\text { European Medicines Agency (EMA) } \\
\text { - Regulation No 726/2004 } \\
\text { - Directive 2001/83/EC }\end{array}$ & $\begin{array}{l}\text { Yes: } \\
\text { Monitoring and } \\
\text { investigation } \\
\text { powers }\end{array}$ \\
\hline & $\begin{array}{l}\text { Health and Safety } \\
\text { at Work }\end{array}$ & $\begin{array}{l}\text { European Agency for Health and } \\
\text { Safety at Work (EU-OSHA) } \\
\text { - Regulation No } 1112 / 2005\end{array}$ & No \\
\hline \multirow{4}{*}{$\begin{array}{l}\text { 15. Social Policy } \\
\text { (shared) } \\
\text { 16. Transport } \\
\text { (shared) }\end{array}$} & $\begin{array}{l}\text { Living and working } \\
\text { conditions }\end{array}$ & $\begin{array}{l}\text { EUROFOUND } \\
\text { - Regulation No } 1365 / 75\end{array}$ & No \\
\hline & Maritime Safety & $\begin{array}{l}\text { European Maritime Safety Agency } \\
\text { (EMSA) } \\
\text { - Regulation No } 1406 / 2002 \\
\text { - Regulation No } 100 / 2013\end{array}$ & No \\
\hline & Railway & $\begin{array}{l}\text { European Railway Authority (ERA) } \\
\text { - Regulation No 881/2004 }\end{array}$ & No \\
\hline & Aviation & $\begin{array}{l}\text { European Aviation Safety Agency } \\
\text { (EASA) } \\
\text { - Regulation No 6/2013 } \\
\text { - Regulation No } 216 / 2008 \\
\text { - Regulation No } 1592 / 2002 \\
\text { OLAF } \\
\text { - Regulation No } 883 / 2013 \\
\text { - Regulation No } 2185 / 96\end{array}$ & $\begin{array}{l}\text { Yes: } \\
\text { Monitoring, } \\
\text { investigation } \\
\text { and sanctioning } \\
\text { powers. } \\
\text { Yes: } \\
\text { Investigation } \\
\text { powers }\end{array}$ \\
\hline
\end{tabular}

